Electrostatics in the Electronics Environment 


\section{Electrostatics in the Electronics Environment}

Charles E. Jowett

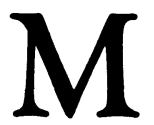


(c) Charles E. Jowett 1976

Softcover reprint of the hardcover 1st edition 1976

All rights reserved. No part of this publication may be reproduced or transmitted, in any form or by any means, without permission

This book is sold subject to the standard conditions of the Net Book Agreement

First published 1976 by

THE MACMILLAN PRESS LTD

London and Basingstoke

Associated companies in New York Dublin Melbourne Johannesburg and Madras

SBN 333194950

ISBN 978-1-349-02907-5 ISBN 978-1-349-02905-1 (eBook)

DOI 10.1007/978-1-349-02905-1

Typeset by

PREFACE LTD

Salisbury, Wilts 


\section{Contents}

Preface viii

Introduction 1

Physics of static electricity 1

Dangers and damage by static electricity 2

1 Dielectrics: Effects of High Static Voltage 7

Conductivity 8

Environmental effects on conductivity $\quad 10$

Capacitance and loss $\quad 11$

Permittivity and dissipation factor measurements $\quad 15$

$\begin{array}{ll}\text { Breakdown tests } & 21\end{array}$

Breakdown in fluids $\quad 25$

2 Static at Dielectrics and Materials Interfaces 29

Static electrification at interfaces $\quad 29$

Solids $\quad 30$

Liquids $\quad 33$

Molecular interface phenomena $\quad 34$

3 Static Electrification of Solids 37

Surface charging by contact $\quad 38$

Surface charging by deformation and cleavage 49

Charge backflow during separation of contacting materials $\quad 52$ 
4 Effects of Static Electrification on MOS Devices 55

Protection methods $\quad 58$

Technological realisation $\quad 65$

5 Static Charge Effects on Thick Film Resistors 71

$\begin{array}{ll}\text { Thick film resistor sensitivities } & 73\end{array}$

$\begin{array}{ll}\text { Thick film resistor models } & 74\end{array}$

6 Static Electrification Hazards 79

Effects of dust $\quad 82$

Organic vapours $\quad 85$

Static on clothing $\quad 86$

7 Protection from Static Electricity 87

Elimination or reduction of static electricity $\quad 87$

Protection of electronic components and finished products by electroconductive foam systems $\quad 88$

Protection of working and production areas by electroconductive foam

Antistatic treatment of products or production areas by special coatings

Ionising surrounding atmospheres $\quad 94$

Appendix 1 Static Electrification Hazard Experiments 95

Materials 95

Apparatus and procedure $\quad 96$

Results with the overalls 99

Resistivity limit for routine testing 104

Appendix 2 Experiments on MOS Devices Gate Protection 107

Dynamic resistance in breakdown 107

Control of breakdown voltage and yield on epitaxial substrates 108

Effectiveness of gate protection $\quad 111$ 
Appendix 3 Accepted Electrostatic Values

Appendix 4 Sample Calculation for the Experimental Failure of a Device Due to a Simulated Discharge of Static Electricity

Device: bipolar silicon integrated circuit, linear building block

Appendix 5 Example of the Calculations Needed to Predict the Approximate Electrostatic Voltage which will Cause Failure of an Integrated Circuit

Device: dipolar silicon integrated circuit, linear building block

Bibliography

Index 


\section{Preface}

Latent problems exist in the handling and processing of many materials having low electrical conductivity. Such materials when being transferred between storage and processing, or production equipment, often build up extremely high electrical charges.

Until recently, very few techniques were generally available for the working and solution of problems involving static electrification. Anyone seeking quantitative information or a means of estimating the magnitude of the accumulation of static electricity, must wade through: abcoulombs, newtons, dynes per statcoulomb, statfarads, abfarads, ergs per second and so on. Most engineers and chemists soon abandon the search for data, and revert to generalisations.

This book deals with the phenomenon of static electrification which is recognised by the presence of electrical charges, either stationary or moving, and through the interaction of these charges - this interaction being solely by reason of the charges themselves and their position, and not by reason of their motion.

Static electrification in electronics is an 'uneven' activity to a very unusual degree. Parts of it are ancient whereas other parts are completely up to date. Static electricity can cause damage to sensitive electronic devices and assemblies, and can create handling, packaging, sorting and storage problems. It can also be a safety hazard in explosion and fire risk areas during the manufacture of devices and equipment.

The facts as presented deal with the problems, the hazards of static electricity in all stages of electronics and the possible means of protection. The work can be read equally by newcomers, interested laymen, technicians and electrical and electronic engineers. 
Grateful acknowledgement for invaluable help is given to the author's many associates, to the manufacturers who so generously furnished data and suggestions and to authors and publishers who permitted inclusion of important parts of the text.

Harpenden, 1976

C.E.J. 